\title{
A SZUBJEKTÍV EGÉSZSÉGI ÁLLAPOT MEGHATÁROZÓ TÉNYEZŐI NYÍREGYHÁZÁN ${ }^{1}$
}

\author{
JóNA GYÖRGY - JÁVORNÉ ERDEI RENÁTA
}

\begin{abstract}
University of Debrecen, Medical Faculty started a bi-yearly repetitive household panel study in Nyiregyháza in 2008 with the management of the Dean Gergely Fabian. In this research series the inhabitants' supposed health conditions were also surveyed besides the social, economic and cultural conditions of one of Hungary's poorest county seats with the involvement of objective and subjective variables.

On the conference he presents the examination results concening the supposed health conditions of the household panel of Nyiregyhaza in 2008 and 2010. However, we can adequately understand these data if we put them into a comparison of regional, national and European Union level. Of course, this time-series research in itself gives a more subtle and accurate picture of the health sociological conditions of the inhabitants of Nyiregyhaza, but we still would like to provide a landscape of a broader spectrum through an international comparison. In our analysis the felt health status is the dependent variable, gender, age, educational level, religion, incomes, employment, interpersonal relation system appear as explanatory variables.

Generally speaking, the subjective health peception of the inhabitants of Nyiregyhaza has deteriorated, especially of women, the younger generation and of those who are around 50-60 years old. Mainly the narrowing financial resources and poverty can be held responsible for this. Educational level is in the closest contact with the felt health status. It is true for Nyiregyhaza too, that the lower education someone has, the more he/she feels ill -sufferers from chronic diseases start to be exceptions from this. Partnerships and social relationships cannot fulfill their health care function, singles thought themselves healthier than people living in marriage. Married, Roman Catholic women between the ages of 50-60 with a secondary level of education reported about the worst health status, their husbands were unemployed and they had low incomes too. Sinking of the middle class to a lower level deepened health inequalities in the town.

In contrast to this, members of the Lutheran confession reported about their stagnant or improving health status, and the rate of old people calling themselves healthy signifi-
\end{abstract}

1 Mindkét háztartáspanel vizsgálat a Debreceni Egyetem Egészségügyi Kar Szociális és Társadalomtudományi Intézet, valamint Nyíregyháza Megyei Jogú Város Polgármesteri Hivatal Szociális Irodája közös támogatásával készült. 
cantly increased (doubled) among the senior generation older then 70 . So as regards the subjective health status, Lutheran men older than 70 with secondary or lower education were in the best position during the two examined years.

Keywords: sociology of health, self-perceived health status, exclusio and health status DOI: $10.19055 / \mathrm{ams} .2012 .3 / 3 / 7$

\section{BEVEZETÉS}

A Debreceni Egyetem Egészségügyi Kara Fábián Gergely dékán irányításával 2008ban indította útjára Nyíregyházán a kétévente ismétlődő háztartáspanel vizsgálatot. Ebben a kutatássorozatban Magyarország egyik legelmaradottabb megye székhelyének társadalmi, gazdasági, kulturális viszonyai mellett a lakosok vélt egészségi állapota is felmérésre került objektív és szubjektív változók bevonásával. ${ }^{2}$

Napjainkban az egészségi állapotot elsősorban szocioökonómiai és demográfiai tényezők határozzák meg, kézenfekvő, hogy szociológiai méréssel adekvát formában ismerhetjük meg a lakosság érzett egészségi állapotának alakulását. Ebben az elemzésben, nemzetközi minták szerint, szubjektív egészségi állapot szerint definiáltuk és operacionalizáltuk az egészségi státuszt (Bentsen - Henriksen - Wenten-Larsen - Hanestad et al. 2008, Nermoen - Husebye - Svartberg - Lovas 2010, Butrick - Peabody Solon - Desalvo et al 2010, Osborn - Paasche - Bailey - Wolf 2011, Hahner - Loeffler - Fassnacht - Weismann 2007, Johnson-Wolinsky 1993, Kaplan-Goldberg és mtsai 1995). Bár több jogos kritika is éri ezt a megközelítést, mi mégis ezt használtuk, mert előnyei felülmúlják általunk is ismert és elfogadott létező hátrányait. A kutató számára nem minden esetben mérhető fel minden részletre kiterjedően a megkérdezett egészségi állapota, ezért jobb eredményeket érünk el akkor, ha maga a megkérdezett mutatja be, illetve értékeli azt (Ware 1986). A válaszadó képes teljes körüen átlátni, megérteni saját egészségi státuszát, teljes egészében ő ismeri egészségét, ezért ez az eljárás alkalmas arra, hogy az egészségi állapotot holisztikusan közelítse meg, illetve mérje. Mint a kategória neve is utal rá, ez szubjektív tartalmú kategória, mégis reliabilitását több vizsgálat is alátámasztotta, sőt, rendszerint prediktív funkciói pontosabbak, mint az orvosi (objektív) mérésé (Tahin - Jeges - Lampek 2000). Emellett érvel Pikó is, aki szerint „az ún. önminősített egészségi állapot szubjektív értékelés, azonban az objektív fizikai státusszal is szorosan összefügg, ezért alkalmas a betegségfolyamatok monitorozására." (Pikó 2006: 52) Ellenben a kategória validitása már rosszabb, valamint a nemzetek közötti kulturális preferenciák különbözőségéből származó magatartásbeli eltérések is torzító hatást eredményezhetnek (Tokaji-Faragó-Boros 2011). A fogalom alkalmazott kutatásba való bevonása nem minden esetben eredményez pontos mérést, vizsgálatunkban mégis ezt alkalmazzuk, mert - bár informatív módon - a társadalom, illetve a lokális társadalom egészségérzetét jól prezentálja. A szubjektív egészségi állapot

2 A szubjektív egészségi állapot, a vélt (self-perceived) egészségi állapot és az érzett egészségi állapot kategóriáit nemzetközi standardok alapján egymás szinonimáiként alkalmazzuk, ezek egymással felcserélhetőek. 
kategóriája hazai és nemzetközi tudományos vizsgálatokban általánosan elfogadott. Erre elsőként igazán erőteljesen a magyarul is olvasható úgynevezett Stiglitz-jelentés hívta fel a figyelmet (Stiglitz-Sen-Fitoussi 2009), amit később a Marmot jelentés (2010) is alkalmazott, illetve megerösített.

Elemzésünkben az érzett egészségi státusz a függő változó, a nem, kor, iskolai végzettség, vallás, jövedelem, foglalkoztatottság, interperszonális viszonyrendszer pedig magyarázó változóként szerepel.

Ki kell emelni, hogy az objektív indikátorokat nem cseréljük le szubjektívvel, hanem kiegészítjük vele: az objektív és szubjektív változókat egyszerre használjuk, egyiknek sem tulajdonítunk döntő funkciót, egyiket sem abszolutizáljuk. Nem zárjuk ki egyiket sem, a kettő egymással komplementer viszonyban áll, ezek együttes alkalmazásával még árnyaltabb képet kapunk a helyi lakosok egészségi státuszáról (TokajiFaragó-Boros 2011).

Ez a tanulmány tehát a 2008-as és 2010-es nyíregyházi háztartáspanel vélt egészségi állapotra vonatkozó vizsgálati eredményeit mutatja be. Ezeket az adatokat azonban akkor tudjuk adekvát módon értelmezni, ha regionális, országos és európai uniós szintü összehasonlításba helyezzük. Természetesen ez az idősoros kutatás már önmagában is árnyaltabb, pontosabb képet nyújt a nyíregyházi lakosok egészségszociológiai viszonyairól, mi mégis egy szélesebb spektrumú kitekintést kívánunk nyújtani nemzetközi összehasonlítás révén.

Empirikusan bizonyított, hogy a lokális/regionális vagy városi lakosság egészségi állapotát alapvetően az életmód és a gazdasági fejlettség adott foka (ezt általában az egy före jutó GDP-vel szoktuk mérni) határozza meg leginkább (Or 2001). Lalonde (1974) ismert megállapításai alapján ezt a tézist fejlesztette tovább Mihályi Péter (2000: 27-30, 2003: 81-107), aki szerint a lakásviszonyok, az iskolai végzettség, a társadalmi munkamegosztásban elfoglalt pozíció, valamint a jövedelem és vagyon mértéke mint szociokulturális-gazdasági háttérváltozók együttesen befolyásolják az életmódot (ez utóbbit magyarázó változóként definiáljunk), ami pedig végül kihat az egészségi státuszra. Pikó is ezt a négy tényezőt emeli ki (Pikó 2006: 87), amit mi kiegészítünk még a kor, nem, vallás, interperszonális viszonyok és a családi állapot változókkal. Természetesen tisztában vagyunk azzal, hogy ezen a faktorok hatásai csupán teoretikus módon választhatók szét, a gyakorlati életben ezek szerves módon kapcsolódnak egymásba, egymást erősítve együttesen fejtik ki hatásukat. Ezek elméleti bontására azért volt szükség, mert ez megkönnyíti az elemzést, illetve az értelmezést. Ebben a tanulmányban tehát e megismerési modell alapján elemezzük a nyíregyházi lakosok egészségi állapotának alakulását.

\section{KUTATÁSI EREDMÉNYEK}

A szubjektív egészségi állapot Magyarországon szinte már hagyományosan rossznak nevezhető. Az 1. sz. ábrából egyértelmủen kiderül, hogy az európai társadalmak közel kétharmada jónak tartja egészségi állapotát, az elfogadható és jó egészségi állapot tekintetében Nyíregyháza meghatározó arányban le van maradva az EU-s átlagtól. 


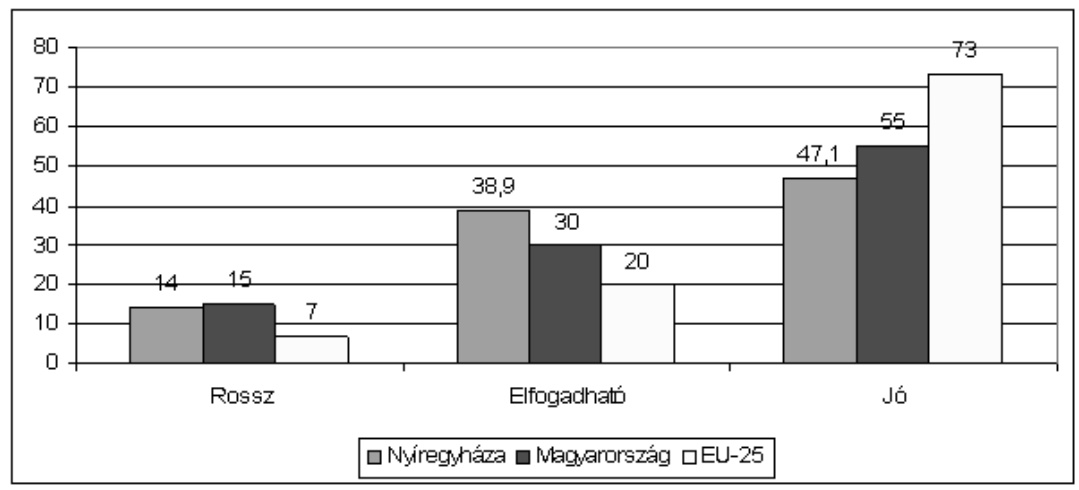

1. ábra - Szubjektív egészségi állapot nemzetközi, hazai és nyíregyházi összehasonlítása 2008-ban. (\%)

Ennek a kedvezötlen helyzetnek többek között szociológiai és szociálpszichológia magyarázata van, amit akár társadalomtörténeti aspektusból is lehet elemezni. Elöször is, nem szabad szem elöl téveszteni, hogy a magyar társadalomban a panaszkodásnak, a hátrányos állapotok kihangsúlyozásának, negatív, desktruktív attitüdnek szinte már megszilárdult és kikristályosodott tradíciói vannak. A hazai kulturális sémák szerint a társas interakciókban nem sért semmilyen írott vagy iratlan normát az, ha valaki betegségéről beszél konkrétan, ezt akár még szegénységével is összekapcsolja. Nemzetközi iratlan szabályok, világértelmezési sémák, tradíciók és a protokoll szerint ezt kerülni kell. Nem véletlen tehát, hogy a magyar szubjektív egészségi állapot ennyire rossz és tőlünk nyugatabbra ez az arányszám sokkal kedvezőbb helyzetet mutat. Ugyanakkor arról sem szabad elfeledkezni, hogy a 2008-as hitelválság következtében kialakuló káros társadalmi, gazdasági folyamatok is jelentősen meghatározzák egy társadalom egészségi állapotát. A rossz egészségi állapotra utaló jelek tehát nem csak a kulturális mintázatokkal, tradíciókkal, hanem objektív faktorokkal is magyarázhatók.

A háztartáspanel vizsgálatban a nemzetközi gyakorlattal ellentétben nem három, hanem ötfokú skálán mértük az érzett egészségi állapotot, így árnyaltabb képet kaphattunk erről. A 2. sz. ábra szerint a vizsgált két év leforgása alatt is mérhetően romlott a nyíregyházi lakosság egészégi állapota, a nagyon jónak és jónak tartott egészségü lakosok aránya csökkent 5,9 százalékponttal.

A fenti ábráról egyértelműen kiolvasható, hogy egy igen gyors ütemű deklasszálódás strukturálta át a nyíregyháziak egészségi közérzetét, ami a hazai állapotokat követi. A táblázatból az derül ki, hogy a nagyon jónak és jónak minősített egészségi státuszhoz tartozók aránya csökkent, ezek átkerültek az elfogadható kategóriába, a rossznak és nagyon rossznak tartott egészségüek száma pedig kismértékben emelkedett. Ezek a folyamatok valószínüleg a 2008-as hitelválság hatásával is szignifikáns kapcsolatban állnak (Kollányi 2011).

Igazán érdekes kép bontakozik ki előttünk, ha nemek szerinti bontásban figyeljük 
meg a szubjektív egészségi állapot alakulását. A 3. sz. ábrán jó látható, hogy a nők általában rosszabb egészségi állapotúnak vallották magukat, mint a férfiak, bár az idő múlásával a két nem közötti distancia kiegyenlítődni látszik.

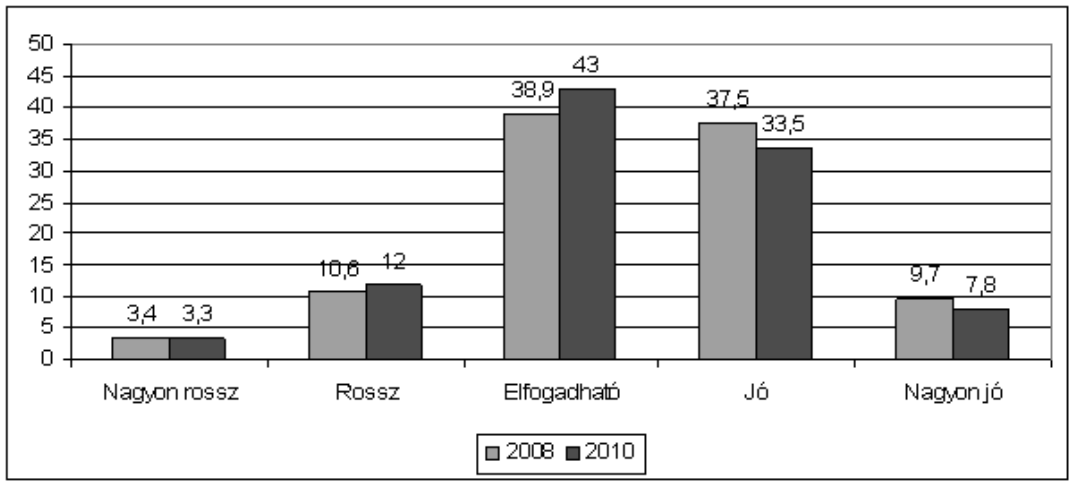

2. ábra - Szubjektív egészségi állapot alakulása Nyíregyházán 2008 és 2010 között. (\%)

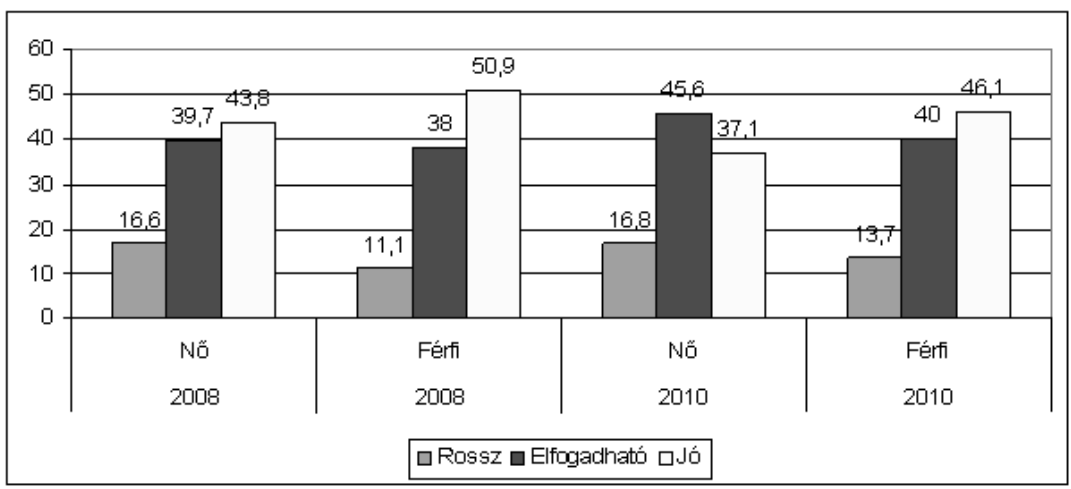

3. ábra - Szubjektív egészségi állapot alakulása nemek szerint Nyíregyházán. (\%)

A jó egészégi állapot mindkét nem esetében romlott, de a nők esetében statisztikailag szignifikánsan is kimutatható ez a tendencia. Lokális szinten az érzett egészségi állapot romlását a nyíregyházi nők súlyosbodó vélt egészségi helyzetével lehet magyarázni. A nők egészségérzetének alakulása igen összetett viszonyban van a társadalmi munkamegosztással, a családi állapottal, a férj jövedelmével illetve az ahhoz tartozó szimbolikus presztízzsel, esetleg privilégiummal. Ez egy igen sajátos reláció, ugyanis - mint azt számos szociológiai felmérés is alátámasztja - a nőket kevésbé viseli meg az, ha 
munkanélkülivé válnak (Bánfalvy 1997). Azonban, ha férjük lesz állástalan, akkor az sokkal erősebb betegségkockázati faktorként jelentkezik, emiatt már rövid idő alatt beteggé válhatnak a nők, amely a családi életen, a szocializációs mechanizmusokon is nyomot hagy, tehát öröklődik. Jellemző, hogy a nők egészségérzete és férjük munkanélkülisége között jelentős mértékü korreláció állapítható meg: azoknak a nőknek romlott a szubjektív egészségi állapota, akiknek a férje a vizsgált két év során munkanélküli lett. Tipikus, hogy tartós munkanélküliek esetében egyetlen egyén sem volt (!), aki azt mondta volna, hogy nagyon jó egészségi állapottal bír még akkor sem, ha a közfoglalkoztatásnak valamelyik típusába tartozott. A közmunka és az elsődleges munkaerőpiaci státusz egészségteremtő funkciója között lényegi különbség mutatkozik. Míg a primer munkaerőpiac világában az egyén karriert építhet, presztízst teremthet, konstruktív identitást szerezhet, a közmunka programban lévő egyén (legyen nő vagy férfi) destruktív önmeghatározást alakít, amely az egészséggel kapcsolatos életminőségét károsan befolyásolja.

Újabb fontos tulajdonsága a város egészségi állapotának, hogy az itt élő nők születéskor várható átlagos élettartama (ami az egészségi állapot egyik igen gyakran alkalmazott helyes indikátora) magasabb, vagyis jobb, mint a férfiaké. Ez nem csak Magyarországon figyelhető meg, nemzetközileg is hasonló tendencia alakult ki. Az lenne logikus, hogy a nők érzett egészségi állapota jobb, mint a férfiaké. Ez azonban nem így van. Ha dinamikájában elemezzük a nemek közötti eltérést, akkor szembetünő különbséget állapíthatunk meg: a nők vélt egészségi státusza jobban romlott, mint a férfiaké. A jó egészségü nők aránya csökkent (43,8\%-ról 37,1\%-ra) az elfogadhatónak minősítettek javára. Abszolút számok nyelvén ez hozzávetőleg 7.000 romló egészségi állapotú nőt jelent csak Nyíregyházán - két év leforgása alatt.

Az 1. sz. táblázatban a társadalomtudományi kutatásokban megszokott korosztályi bontásban elemeztük a vélt egészségi állapot megítélését. Amint az a táblázatból egyből kiderül, a legfiatalabb életkori szakaszba tartozók körében majdnem megduplázódott a rossz egészségi állapot érzete. Az országos tendencia ennek épp az ellentéte. Bár abszolút számban ez meglehetősen alacsonynak nevezhető, mégis jelzésértékủ a fiatal generáció betegségérzetének növekedése. Ennek a káros változásnak a kauzális hátterét nem ismerjük kellő alapossággal.

Jelenleg még azt sem tudjuk pontosan megmagyarázni, hogy az életkor növekedésével - látható, fơként 40 éves kortól felfelé - az egészségi állapot szubjektív megítélése miért javul Nyíregyházán. Egyetlen kivételnek számít a 60 és 69 éves korosztály, csak ebben a csoportban csökkent az egészségesek aránya. Az 1. táblázatból egyértelmüen kirajzolódik, hogy minél idősebb generációkat vizsgálunk 2008 és 2010 összehasonlításában, annál kedvezőbb értékeket találunk a szubjektív egészségi állapottal kapcsolatban. A 40-49 éveseknél 2,3 százalékponttal, az 50-59 évesek osztályában 7 százalékponttal, míg a 70 évnél idősebb csoportban 2,2 százalékponttal javult két év alatt az érzett egészségi állapot. Legrosszabb a helyzet a 18-29 éves, valamint a 60-69 évesek körében, vagyis azoknál, akik most kerülnek ki, illetve most készülnek a társadalmi munkamegosztásban elfoglalni helyüket (akik a fiatal felnött korba lépnek), valamint a nyugdíjba lépőknél. Népegészségügyi szempontból kiemelten veszélyeztetett 
társadalmi csoportok ezek, mert itt majdnem megduplázódott azok aránya, akik 2008hoz képest 2010-ben rossznak tartották egészségüket. Újból hangsúlyozzuk, tentatív jellegü magyarázatot nem szeretnénk erre adni, ennek tudományos elemzése még további empirikus vizsgálatokat igényel, e jelenség hátterében megbúvó okokat nem, vagy csak homályosan ismerjük (Havasi 2011).

\begin{tabular}{|l|l|l|l|l|l|l|l|l|l|}
\hline & \multicolumn{3}{|l}{2008} & \multicolumn{3}{l}{2010} & \multicolumn{2}{l|}{ Változás (százalékpont) } \\
\hline $\begin{array}{l}\text { Korosz- } \\
\text { tály }\end{array}$ & Rossz & $\begin{array}{l}\text { Elfo- } \\
\text { gadható }\end{array}$ & Jó & Rossz & $\begin{array}{l}\text { Elfo- } \\
\text { gadható }\end{array}$ & Jó & Rossz & $\begin{array}{l}\text { Elfo- } \\
\text { gadható }\end{array}$ & Jó \\
\hline $18-29$ & 1,1 & 15,6 & 83,3 & 3,1 & 16,5 & 79,3 & 2,0 & 0,9 & $-4,0$ \\
\hline $30-39$ & 3,0 & 22,5 & 74,5 & 3,0 & 27,6 & 69,0 & 0,0 & 5,1 & $-5,5$ \\
\hline $40-49$ & 7,6 & 38,2 & 54,1 & 5,3 & 40,5 & 54,1 & $-2,3$ & 2,3 & 0,0 \\
\hline $50-59$ & 23,8 & 46,6 & 29,6 & 16,8 & 58,0 & 24,7 & $-7,0$ & 11,4 & $-4,9$ \\
\hline $60-69$ & 14,6 & 65,7 & 19,8 & 29,2 & 60,9 & 9,9 & 14,6 & $-4,8$ & $-9,9$ \\
\hline $70-$ & 44,4 & 48,1 & 7,5 & 42,2 & 43,8 & 14,0 & $-2,2$ & $-5,3$ & 6,5 \\
\hline
\end{tabular}

1. táblázat - Szubjektív egészségi állapot korosztályok bontásában Nyíregyházán. (\%)

A családi állapot is döntő hatással van az egészségi állapotra, Nyíregyházán azonban fordított befolyása van ennek a faktornak, egészségkárosító hatása van. Azt lehet látni, hogy a nőtlen, illetve hajadon kategóriába tartozók érzett egészségi állapota stagnál, míg a többieké romlik. Ennek strukturális okai ismerjük, amely elég kedvezőtlen helyzetre enged következtetni. Társadalomtudományi vizsgálatokból ismert tény, hogy a párkapcsolatban vagy házasságban élők egészsége jobb, mint az egyedülállóké (Hajnal 2010). Ám ez a megállapítás csak azzal a megszigorítással fogadható el, ha az érintett egyének kiegyensúlyozott, boldog, harmonikus kapcsolatban élnek egymással. Bumeráng-effektus alakul ki akkor, ha rossz viszony alakul ki a felek között: nagyobb a betegségkockázati tényezők ereje (föként férfiak esetében az öngyilkosság esélye nő meg) abban az esetben, ha valaki rossz házas- vagy párkapcsolatban él. Egy rossz partnerviszony beteggé teszi az egyént ahelyett, hogy egészségmegőrző funkcióját kifejtené. Ezzel állunk szembe Nyíregyházán is: a 4. sz. ábra azt mutatja, hogy a szingliként élők körében nem változott az érzett egészségi állapot a káros gazdasági-társadalmi folyamatok ellenére, míg a többi kategóriában romlott. Még az élettársi viszonynak is erősebb egészségmegőrző hatása van, mint a házasságnak. Ez a nyíregyházi házasságok diszfunkciójára utal.

Jól ismert empirikus kapcsolat tárul fel az iskolai végzettség és a szubjektív egészségi állapot között (2. sz. táblázat). Ez azt mutatja, hogy azoknak, akik vizsgálatunk mintavételi keretébe kerültek és csupán alapfokú végzettséggel rendelkeztek, jelentösen romlott az egészségérzetük. A vizsgált periódusban 11,3 százalékponttal nőtt azok aránya, akik ebbe a konglomerátumba tartoznak, ami lokálisan megközelítőleg 10.000 
embert jelent. Egy ilyen rövid idő alatt lezajlódó drasztikus deklasszálódás nyilvánvalóan az érzett egészségi státuszra is rányomja bélyegét. Jellemzően azoknak romlott az egészségi állapotuk, akik 2008-ban még jónak vélték egészségüket, azok aránya pedig nagyjából konstans maradt, akik elfogadhatónak egészségérzettel rendelkeztek.

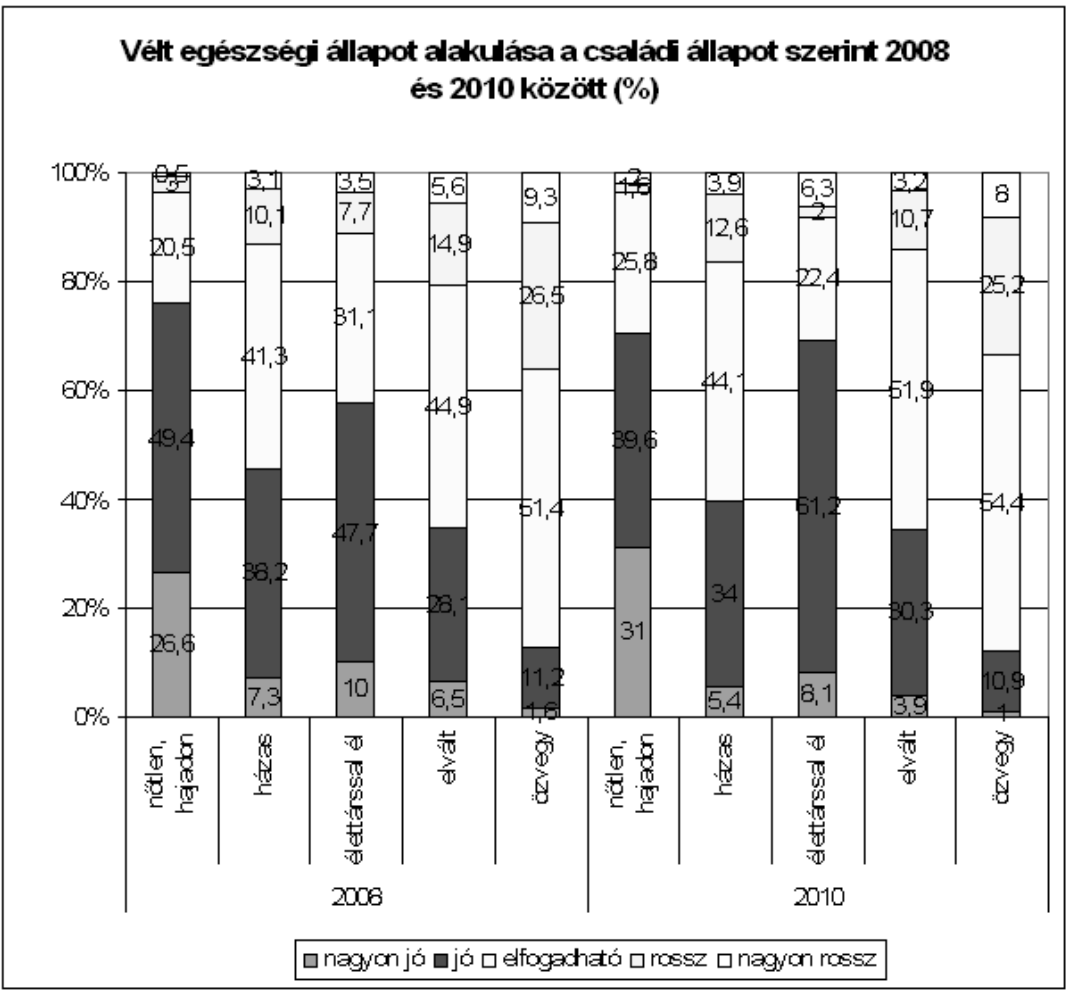

4. ábra - Vélt egészségi állapot alakulása a családi állapot szerint 2008 és 2010 között. (\%)

Az egzisztencia és szubjektív egészségi állapot közötti hatás elemzésénél elsőként fontos tisztázni, hogy a jövedelem és az egészségi állapot között nincs direkt viszony, hanem akár többszörös áttételeken keresztül hat az anyagi helyzet a vélt egészségi állapotra. Attól, hogy valaki magasabb egzisztenciát képest biztosítani magának és családjának, még nem feltétlenül lesz egészségesebb, és fordítva. Viszont a jövedelem elköltésének módja, a család fogyasztói kosarának összeállítása már valódi kapcsolatot eredményez a két változó között. A kölcsönhatás általában az alábbi folyamat szerint formálódik: a magasabb iskolai végzettséggel rendelkező osztályok rendszerint magasabb jövedelemmel is bírnak. A jobb kvalitás általában magasabb egészségügyi ismere- 
teket is feltételez, vagyis a tanultabb és egyben gazdagabb rétegek egészségattitüdje, egészségmagatartása jó, kedvezőbb táplálkozási szokások szerint élnek, szabadidejüket egészségesebben töltik el, többet mozognak, stb. A szegényebb csoportokat ennek ellenkezője jellemzi. „A szegénység és rossz egészségi állapot szorosan együtt jár. A tartós és mélyszegénység betegséghez vezet, a betegség viszont szegénységet szül. Ok és okozat kibogozhatatlan egységével találkozunk.” (Havasi 2011: 81) Más szavakkal, az anyagi helyzet akár több faktoron keresztül, indirekt fejti ki hatását, de azt mégis nagyon erősen teszi.

\begin{tabular}{|l|l|l|l|l|l|l|l|l|l|}
\hline & \multicolumn{3}{|l}{2008} & \multicolumn{3}{l|}{2010} & \multicolumn{3}{l|}{ Változás (\%pont) } \\
\hline $\begin{array}{l}\text { Iskolai } \\
\text { végzett- } \\
\text { ség }\end{array}$ & Rossz & $\begin{array}{l}\text { Elfo- } \\
\text { gadható }\end{array}$ & Jó & Rossz & $\begin{array}{l}\text { Elfo- } \\
\text { gadható }\end{array}$ & Jó & Rossz & $\begin{array}{l}\text { Elfo- } \\
\text { gadható }\end{array}$ & Jó \\
\hline Alap & 30,4 & 50,2 & 19,4 & 41,7 & 45,0 & 13,3 & 11,3 & $-5,2$ & $-6,1$ \\
\hline Közép & 13,3 & 40,8 & 45,9 & 14,4 & 45,6 & 39,5 & 1,1 & 4,8 & $-6,4$ \\
\hline Felső & 6,8 & 28,4 & 64,8 & 6,4 & 36,4 & 56,9 & $-0,4$ & 8,0 & $-7,9$ \\
\hline
\end{tabular}

2. táblázat - Iskolai végzettség és a szubjektív egészségi állapot kapcsolata Nyíregyházán (\%)

Ha az 5. sz. ábrát megfigyeljük, akkor azt láthatjuk, hogy a nyíregyházi szegény és gazdag családok érzett egészségi állapota igazán jónak nevezhető, a jövedelmi hierarchia két végpontján csúcsosodik ki a jónak tartott szubjektív egészségi állapot. Ez a struktúra nem változott két év alatt, sőt tovább tolódott, radikalizálódott a két szélsőérték irányába. A tehetősebb rétegek aránya megháromszorozódott (12\%-ról 36,7\%-ra), a szegények aránya majdnem másfélszeresére (12\%-ról 19,5\%-ra) nőtt a nagyon jó egészségi állapotnak örvendők kategóriájában. Ennek a hátterében valószínüleg egy sajátos látencia húzódik meg, a szegény családok egy bizonyos szegmense szégyelli periférikus helyzetét, ők a növekvő exklúzió miatt inkább a rejtőzködést választják, félnek a többségi társadalom stigmatizálásától. Úgy próbálnak meg bennmaradni a társadalom szerkezetében, hogy a fogyasztói társadalom és a globalizáció reklámjaiból ismert termékekkel veszik körül magukat (akár hitelre is vásárolnak) és boldognak, egészségesnek titulálják magukat.

A szegények döntő része azonban nyíltan vállalja romló egészségi állapotát, erre utal az is, hogy 4,1\%-ról 14,2\%-ra emelkedett a nagyon rossznak minősítést kapók aránya.

Legrosszabb a helyzet a deklasszálódó csoportok esetében, a középosztálynál (itt majdnem kilencszer többen tartották egészségi állapotukat nagyon rossznak 2010-ben, mint 2008-ban). Szociológiai evidencia, hogy azokban a társadalmi rétegekben legnagyobb az elégedetlenség, a romló miliő, ahol a lefelé irányuló társadalmi mobilitás elkezdődik, illetve elkezdődött, itt lángolnak fel legerősebben a társadalom parázs vitái. ${ }^{3}$ Nem feltétlenül ez az osztály van a társadalmi hierarchia alján, mégis a kiábrándulás és a talajvesztés itt jelenik meg szembetünően. Ez tapasztalható Nyíregyházán is. Szig-

3 Erről részletesen lásd a tanulmánykötetben Balogh Erzsébet - Fábián Gergely közös tanulmányát. 
nifikáns romlás figyelhető meg az alsó- és felsőközéposztályok esetében, olyan elszegényedés, csalódottság és velejáró szubjektív egészségromlás alakult ki, mely csak válság idején szokott lenni.

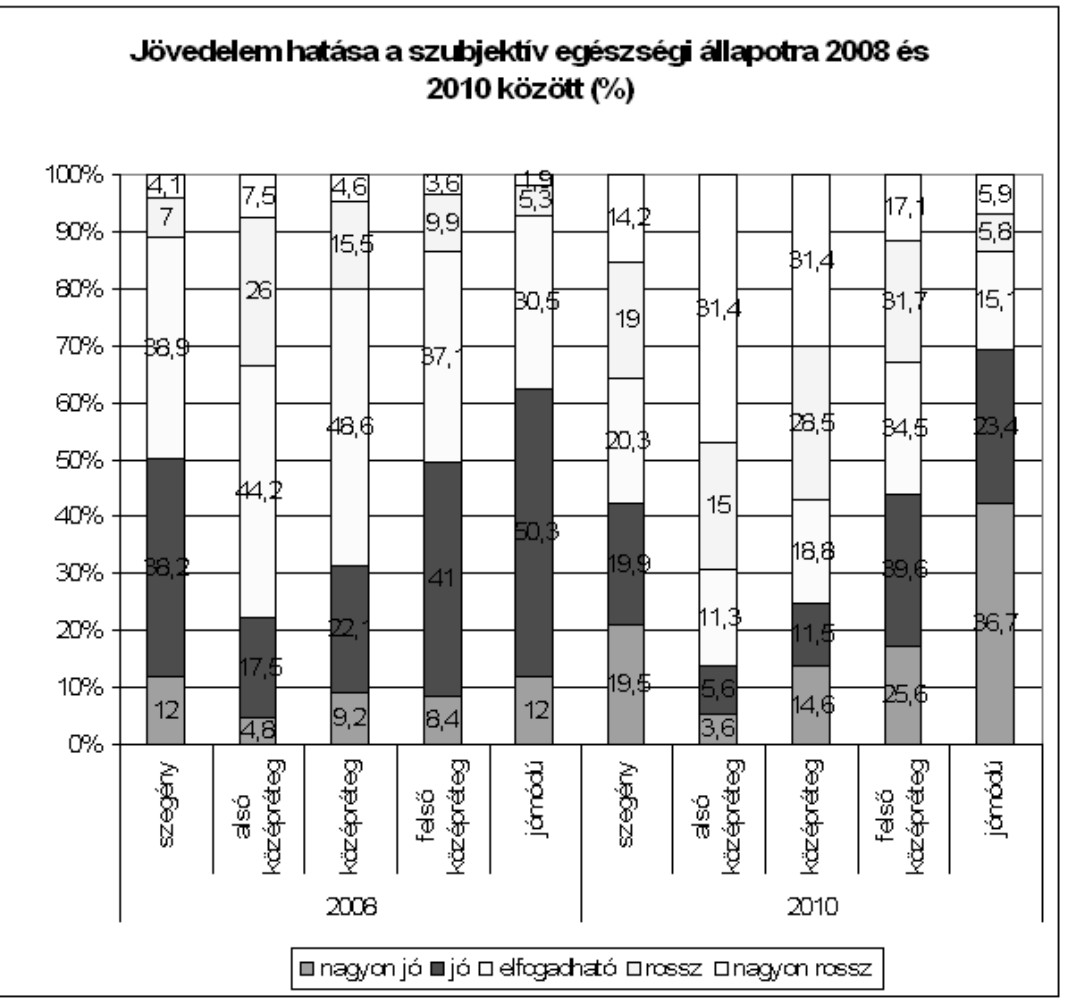

5. ábra - Jövedelem hatása a szubjektív egészségi állapotra 2008 és 2010 között. (\%)

A lakásviszonyok elég jellegzetesen befolyásolják az érzett egészségi állapot státuszát. A lakás alapterülete és a szobák száma lényegesen nem meghatározó ebben az összefüggésben, viszont a komfortfokozat már jelentős hatással van. Mindenekelőtt az aládúcolt, zajos lakás (nem a zajos környezet, inkább a zajos szomszédok megléte), a nyirkos falak, a dohos és sötét szobák, a melegvíz-ellátás és a gázellátás hiánya rontja az egészségi állapotot, valamint az, ha a lakásnak olyan hibája van, amely a mindennapi életminőséget károsítja. A környezetszennyezéssel kapcsolatos faktorok és a környéken élők deviáns személyek magatartásformái szintén szignifikánsan rontják az egészségi állapotot. A lakás és egészségi státusz közötti reláció 2008 és 2010 között nem változott, a változók közötti kapcsolat erőssége jelentősen nem rendeződött át. 
A nyíregyházi lakosság valláshoz való viszonya a vizsgált két év alatt csupán részlegesen alakult át. 2,4 százalékponttal (statisztikailag részlegesen szignifikánsan) csökkent azok aránya, akik az egyház doktrínáihoz hủnek tartották magukat, formálisan is valamely felekezet tagjai voltak. Ha összevonjuk azokat, akik hivatalosan hívőnek tartották magukat és a magukat vallásosnak tekintett személyeket (ők úgy határozták meg vallásosságukat, hogy „hiszek a magam módján, de nem vagyok tagja egyik egyháznak sem”), akkor azt lehet mondani, hogy ebben a két évben Nyíregyháza polgárainak közel kétharmada vallásosnak volt nevezhetö. A szekularizációs folyamatok nem, vagy csak korlátozott mértékben bontakoztak ki.

A vallásos életmód kedvező hatása az egészségi állapotra már régóta ismert és bizonyított (Pikó 2002: 124-161). A vallásos közösségben élők egészségmagatartása általában jobb, mint a vallás nélkülieké, mert hitük miatt nem esznek annyira füszeresen, bizonyos vallásokban tilos disznóhúst enni, az alkohol- és cigarettafogyasztás is tiltva van, stb. Nyíregyházán a vallás és az érzett egészségi státusz közötti kapcsolat érdekesen alakult (lásd a 6. sz. táblázat), ugyanis 2008-ban majdnem kétszer annyi magukat nem vallásosnak tekintő személy ítélte jobbnak egészségi állapotát, mint vallásos, míg a valamilyen felekezethez tartozók 42,6\%-a mondta, hogy jó és nagyon jó érzett egészségi állapottal rendelkezik. A vallásos egyének egészségi állapota rosszabb, mint a nem vallásosaké. A várt eredmények fordítottja következett be, ami 2010-re még csak tovább fokozódott. Azok körében javult a vélt egészségi státusz, akik nem illeszkedtek be semmilyen vallási gyülekezetbe. Ennek okait sem ismerjük pontosan.

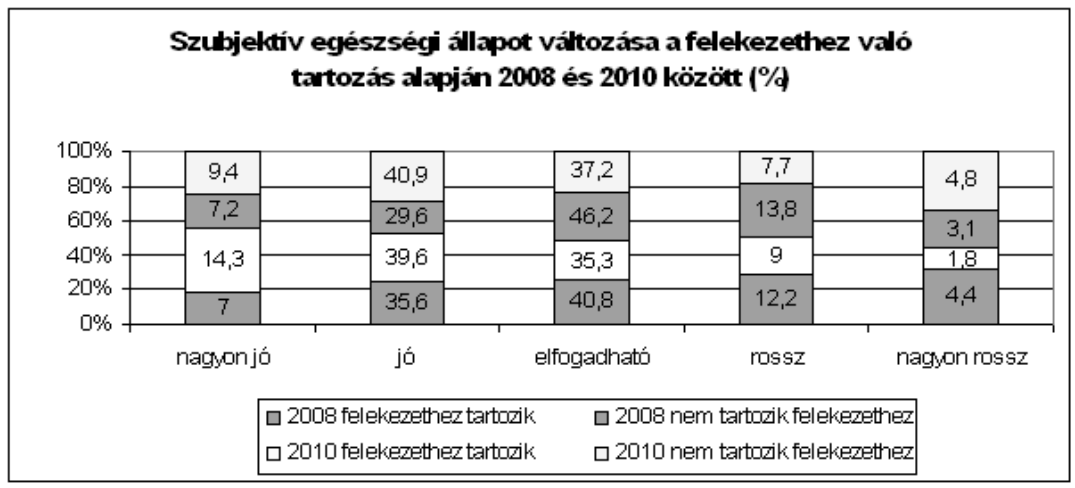

6. sz. ábra - Szubjektív egészségi állapot változása a felekezethez való tartozás alapján 2008 és 2010 között. (\%)

Plasztikusabb képet kapunk, ha a felekezeti bontás szerint vizsgáljuk az érzett egészségi állapotot (érdekes adalékként jegyezzük meg, hogy a rejtőzködés mindkét évben ezen a területen volt a legnagyobb, a válaszadók csupán $50-52 \%$-a válaszolt ezekre a kérdésekre). A 7. sz. ábrából az olvasható ki, hogy 2008-ban sorrendben a görög katolikus, a római katolikus, református végül pedig az evangélikus felekezethez tartozók 
egészségi állapota volt a legjobb (a jó és nagyon jó válaszokat összevonva jött ki ez az eredmény). Ha csak a „nagyon jó” válaszokat nézzük, akkor kiegyensúlyozott viszonyok tárulnak fel, kivételt képeznek ez alól a református egyházhoz tartozók, mindhárom felekezet hívei azonos arányban (nagyjából 8\% körül) képviseltetik magukat, míg a református hívek aránya csak 4,5\% volt.

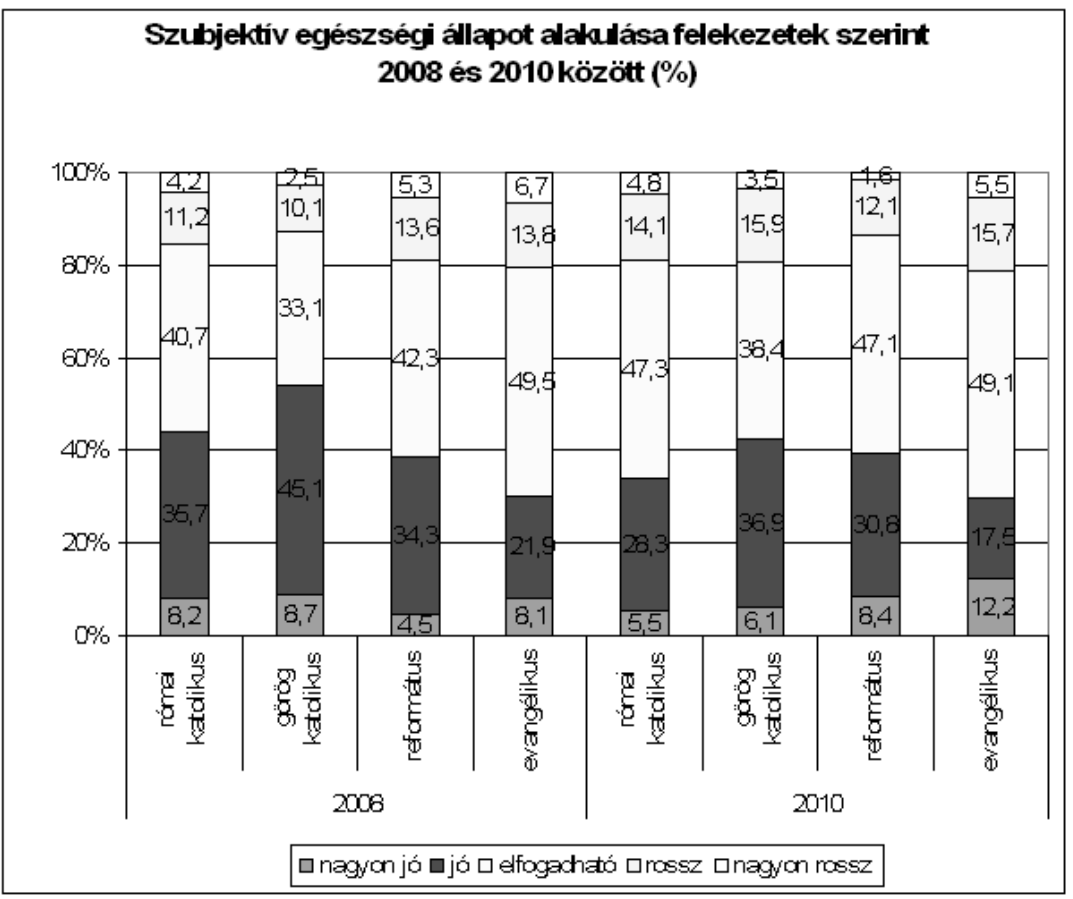

7. ábra - Szubjektív egészségi állapot alakulása felekezetek szerint 2008 és 2010 között. (\%)

2010-re részlegesen átrendeződtek a viszonyok, nagyjából minden felekezethez tartozó egyén arról számolt be, hogy romlik az egészsége. A görög katolikus egyház hívei voltak a legegészségesebbek, ám második helyét elveszítette a római katolikus egyházhoz tartozók, helyükre a református hívek kerültek. A reformátusok körében nagyjából 75\%-kal csökkent a nagyon rossz egészségüek aránya. Viszont további javulás tapasztalható a nyíregyházi evangélikus egyházhoz tartozók körében, ahol 2010-re 8,1\%-ról 12,2\%-ra emelkedett a nagyon jó egészségnek örvendők.

A társas támogatás és az egészségi státusz közötti pozitív reláció az 1970-es évek végétől vált empirikusan bizonyítottá, kutatásunkba ezt az ismérvet is beemeltük. A 8 . sz. ábrából látszik, hogy 2008-ban azok panaszkodtak legtöbbet rossz egészségi állapotukról, akiknek 1-5 barátjuk volt, valamint akik 26-nál több barátról számoltak. Ez a 
tendencia 2010-re semmit sem változott. A baráttal nem rendelkezők aránya sem módosult sokat ebben a két évben. E három válaszadói kör igazán érdekes jelenséget vet fel: azt várnánk az elözetes nemzetközi adatokból, hogy minél több barátja van valakinek, annál egészségesebb. Első ránézésre nem ez látszik, de ha a jelenség mélystruktúráiba betekintünk, észrevehetjük, hogy ezek az adatok illeszkednek a korábbi teoretikus-empirikus megállapításokhoz. Hipotézisünk szerint (amit empirikusan nem tudunk most itt bizonyítani, de erős sejtésünk van róla) azért van felülreprezentálva a 26 barátnál többel rendelkezők csoportja a nagyon rossz egészségüek között, mert aki ilyen sok baráttal rendelkezik, annak valójában egy sincs. Valószínúleg ezzel magyarázható, hogy ennél a kategóriánál a betegségérzet nem csökken, hanem szignifikánsan emelkedik (27,7\%-ról 37,7\%-ra) és magas.

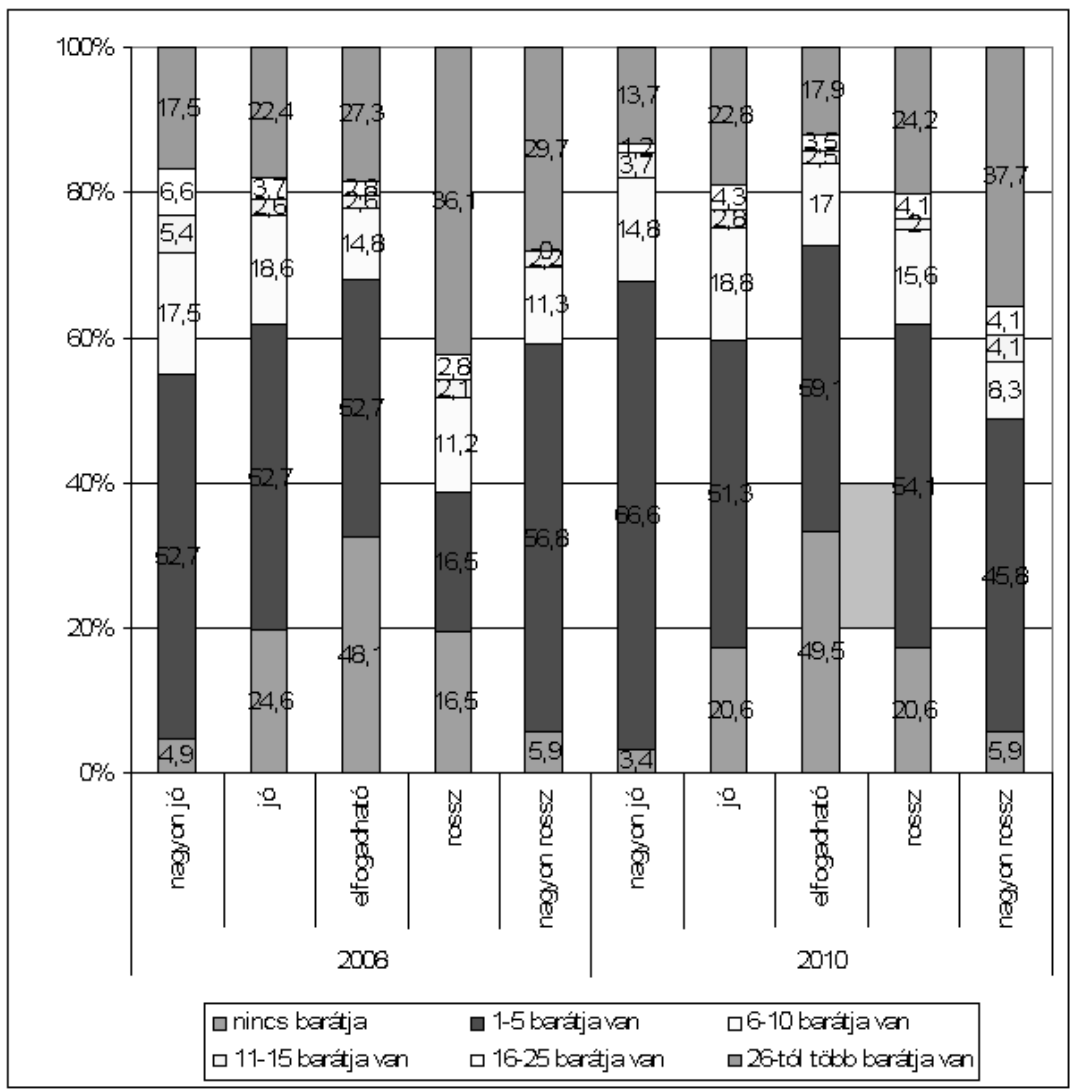

8. ábra - Barátok száma és szubjektív egészségi állapot. 
A krónikus betegek aránya Nyíregyházán nagyjából megegyezik az országos átlaggal: 2008-ban a megkérdezettek 36,9\%-a, míg 2010-ben 37,7\%-a mondta azt, hogy valamilyen állandó, hosszantartó betegségben szenved. A krónikus betegségben szenvedő nők aránya 2010-ben 2008-hoz képest lecsökkent 41,2\%-ról 40,4\%-ra. Az állandó betegségről panaszkodó férfiak aránya azonban nőtt, 2008-ban a megkérdezettek 31,9\%-a, 2010-ben 34,4\%-a mondta magát ilyen betegnek.

Napjainkban az egészségi állapottal összefüggésben álló empirikus felmérésekben, a jól-lét vizsgálatánál a szubjektív egészségérzet mellett a korlátozottságot is mérik, ami a leggyakrabban krónikus betegségekkel állnak összefüggésben. 2010-ben a magyar társadalom 69\%-a mondta azt, hogy betegsége valamilyen formában korlátozza öt a mindennap tevékenységek elvégzésében - ez az átlag természetesen meglehetősen nagy szórású, lokálisan/regionálisan jelentős differenciálódások tapasztalhatóak ebben az összefüggésben (Ambrus-Varsányi 2011: 231). A nyíregyházi adatok ettől messze jobb képet mutatnak: 2008-ban a válaszadók 48,8\%-a, 2010-ben 50,5\%-a vallotta azt, hogy van olyan betegsége, mely bizonyos fokban korlátozza őt a mindennapi tevékenységében.

A 9. sz. ábra alátámasztja azt a ma már szinte egészségszociológiai evidenciát, hogy az alacsony iskolai végzettségüek körében magasabb valószínüséggel alakul ki krónikus betegség, mint a magasabb végzettségüeknél, a diploma bizonyos fokig „megvéd” a tartós betegségtöl. Ez a védelem persze nem determinisztikus, ezt támasztja alá ez az ábra is. Már magasabb arányban jelentkeznek krónikus betegségek alacsonyabb iskolai végzettségüeknél, mégis a vizsgált két év alatt csökkent az alacsony és középfokú végzettségủek csoportjában a krónikus betegség, míg a felsőfokú végzettségủeknél ez az arányszám 25,1\%-ról 31,6\%-ra emelkedett. Ez a növekedés azért is figyelemreméltó, mert csupán két év alatt történt. Ezek az adatok még kedvezőtlenebbek, ha az Európai Unió 25 államának átlagával hasonlítjuk össze: ott 2008-ban az alapfokú végzettséggel rendelkezők 44\%-a, középfokú végzettséggel rendelkezők $26 \%$-a, míg a felsőfokú végzettséggel rendelkezők között $24 \%$-a volt krónikus beteg.

A megkérdezettek betegségei szinte teljesen megegyeznek az országos adatokéval: a legtöbben magas vérnyomással küszködnek, de sokan allergiásak, a cukorbetegség és szívbetegség is számos egyént betegít. Ezek a leggyakrabban említett betegségek a helyiek között. A testi és/vagy szellemi fogyatékosság nincs, vagy alig van hatással a vélt egészségi helyzetre, a betegségtudat töredezetten jelenik meg ebben a csoportban. Legrosszabb a helyzet azok esetében, akiket az elmúlt négy évben kezeltek (tehát egészségügyi intézményi keretek között ápolták) magas vérnyomással, szívinfarktussal, koleszterinnel kapcsolatos betegséggel, cukorbetegséggel, krónikus légzőszervi betegséggel, daganatos betegséggel vagy asztmával.

A háziorvoshoz való fordulás gyakorisága és a vélt (tehát szubjektív és objektív) egészségérzet között figyelemreméltó viszony található. Azok tartották magukat a legbetegebbnek, akik egyszer sem keresték fel háziorvosukat, valamint azok, akik havonta legalább egyszer. Tehát azok a legbetegebbek, akik gyakran, és akik egyáltalán nem keresik fel orvosukat. Az objektív és a szubjektív betegségtudat sajátos együttállása alakult ki a nyíregyháziak körében. A szakrendelések felkeresése és a szubjektív egészségi állapot között már az elözőtől eltérő mintázat formálódott: azok tulajdonítottak 
maguknak rossz egészségi állapotot, akik évente kétszer illetve négyszer kereték fel a szakrendelőt. A fogorvos látogatottsága lehangoló képet fest: a nyíregyházi lakosság 38,5\%-a egyáltalán nem ellenőrizteti fogait. Az előzőekhez képest teljesen fordított a helyzet ebben a konstellációban: minél többször volt valaki fogorvosnál, annál jobbnak ítélte egészségi állapotát, és fordítva.

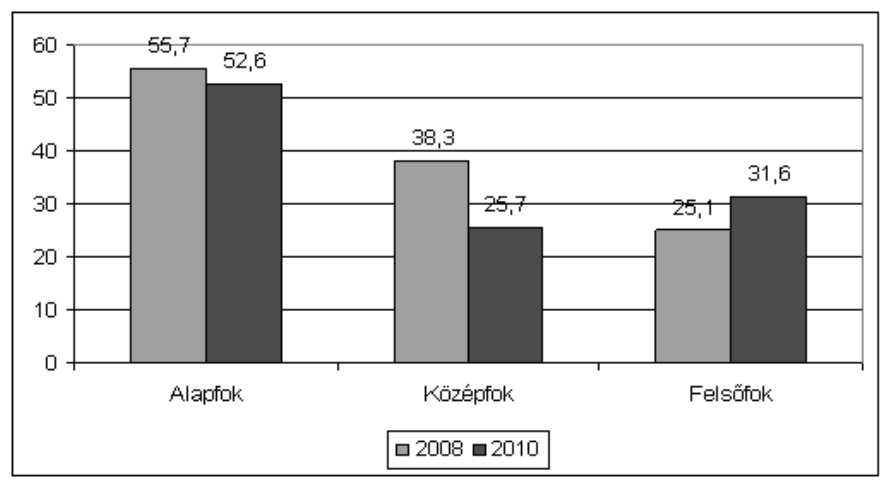

9. ábra - Tartós betegek arányának alakulása az iskolai végzettség szerint 2008-2010 között. (\%)

A helyi társadalom tagjai átlagban $10.000 \mathrm{Ft}$-ot fordítottak egészséggel kapcsolatos kiadásaikra, 2010-ben ez az összeg megmaradt 10.000 Ft körül. Nominálértéken számolva ez konstans maradt, de vásárlóértékét tekintve ez meredek csökkenést jelent. Jellemzően azokban a családokban volt a leggyakoribb a betegségtudat, ahol 2.00014.000 Ft-ot költöttek egy hónapban ezekre az ellátásokra a vizsgált két év alatt. Az egyedüli változás, hogy az egészségügyi ellátásokért fizetett havi összeg alsó határa 2.000 Ft-ról 5.000 Ft-ra emelkedett, ami valószínủleg a gyógyszerár emelkedéssel hozható összefüggésbe. A megkérdezettek közel 9 százaléka közgyógy-ellátásban részesült, jellemzően körükben a legrosszabb a vélt egészségi állapot indikátora. Jó hír viszont, hogy a lakosság jónak minősítette a helyi egészségügyi ellátórendszert a forrás hiányok, illetve alulfinanszírozás ellenére is mindkét évben.

\section{ÖSSZEFOGLALÁS}

A kutatássorozat eredményeit összefoglalva azt lehet mondani, hogy a nyíregyházi lakosok szubjektív egészségérzete romlott, különösen a nőké, a fiatalabb generációé és az 50-60 év körülieké. Ezért föként a szükülő anyagi források, a szegénység tehető felelőssé. Az iskolai végzettség áll legszorosabb kapcsolatban az érzett egészségi státuszszal, Nyíregyházára is igaz, hogy minél alacsonyabb végzettséggel rendelkezik valaki, annál betegebbnek érzi magát - ez alól kivételt kezdenek képezni a krónikus betegségben szenvedők. A párkapcsolatok és a társas kapcsolatok nem tudják betölteni egész- 
ségvédelemmel kapcsolatos funkciójukat, az egyedülállók egészségesebbnek tartották magukat, mint a házasságban élők. A legkedvezőtlenebb egészségi állapotról azok számoltak be, akik 50-60 év közötti házas, római katolikus, középfokú iskolai végzettséggel rendelkező nők voltak, férjük munkanélküli volt és ők is alacsony jövedelemmel rendelkeztek. A középosztály deklasszálódása tovább mélyítette az egészségi egyenlőtlenségeket a városban.

Ezekkel ellentétben az evangélikus felekezet tagjai stagnáló, illetve javuló egészségi állapotukról számoltak be, valamint a 70 évnél öregebb nemzedék körében nőtt szignifikánsan nőtt (megduplázódott) a magukat egészséges idősnek nevezők aránya. Szubjektív egészségi állapot tekintetébe a vizsgált két év periódusában tehát a legjobb helyzetben azok az evangélikus férfiak voltak, akik közép- vagy alapfokú végzettséggel rendelkeztek és 70 évnél idősebbek voltak.

\section{IRODALOM}

1. Ambrus Zoltánné - Varsányi Tamás (2011): Az egészség és az életmód regionális különbségei. Területi Statisztika, 3: 227-245.

2. Bánfalvy Csaba (1997): A munkanélküliség. Budapest: Magvető Kiadó.

3. Bentsen, S. B. - Henriksen, A. H. - Wenten-Larsen, T. - Hanestad, B. R. Wahl, A. K. (2008): What determines subjective health status in patients with chronic obstructive pulmonary disease: importance of symptoms in subjective health status of COPD patients. Health and quality of life outcomes, 6 : 115-119.

4. Butrick, E. - Peabody, J. W. - Solon, O. - Desalvo, K. B. - Quimbo, S. A. (2010): Subjective health status in men and women with congenital adrenal hyperplasia: a A Comparison of Objective Biomarkers With a Subjective Health Status Measure Among Children in the Philippines, Asia-Pacific journal of public health, 12: 223-234.

5. Hahner, S. - Loeffler, S. - Fassnacht, M. - Weismann, D. et. al. (2007): Impaired Subjective Health Status in 256 Patients with Adrenal Insufficiency on Standard Therapy Based on Cross-Sectional Analysis The Journal of Clinical Endocrinology \& Metabolism, 10: 3912-3922.

6. Hajnal Béla (2010): A szocioökonómiai státusz hatásai a jó egészségi állapot hosszára az Európai Unióban. Statisztikai Szemle, 12: 1263-1266.

7. Havasi Éva (2011): A megtört egészség - a hazai lakosság egészségi állapotának egyenlötlenségei, különös tekintettel a szegényekre. Népegészségügy, 2: 80-93.

8. Johnson, R. - Wolinsky, F. (1993): The structure of health status among older adults. Journal of Health and Social Behavior, 34: 105-121.

9. Kaplan, G. A. - Goldberg, D. E. - Everson, S. A. - Cohen, R. D. - Salonen, R. - Toumilehto, J. - Salonen, J. (1995): Perceived health status and morbidity and mortality. International Journal of Epidemiology, 25: 259-265. 
10. Kollányi Zsófia (2011): A gazdasági fejlődés és az egészségi állapot elméleti összefüggései. Népegészségügy, 2: 93-102.

11. Lalonde, Marc (1974): A new perspecitve ont he helath of Canadians. http://www.phac-aspc.gc.ca/ph-sp/pdf/perspect-eng.pdf

12. Marmot, M. (2010): Fair society, healthy lives. http://www.marmotreview.org/AssetLibrary/pdfs/Reports/FairSocietyHealthyLives.pdf

13. Mihályi Péter (2000): Magyar egészségügy: diagnózis és terápia. Budapest: Springer Orvosi Kiadó.

14. Mihályi Péter (2003): Bevezetés az egészségügy közgazdaságtanába. Veszprém: Veszprémi Egyetemi Kiadó.

15. Nermoen, I. - Husebye, E. S. - Svartberg, J. - Lovas, K. (2010): Subjective health status in men and women with congenital adrenal hyperplasia: a population-based survey in Norway. European Journal of Endocrinol, 163: 453459.

16. Or, Z. (2001): Exploring the effects of health care on mortality across OECD countries. OECD Labour Markets and Social Policy Occasional Papers. No. 46.

17. Osborn, C. Y. - Paasche, J. K. - Bailey, S. C. - Wolf, S. M. (2011): The Mechanisms Linking Health Literacy to Behavior and Health Status. American journal of health behaviour, 1: 118-128.

18. Pikó Bettina (2002): Egészségszociológia. Budapest: Új Mandátum Kiadó.

19. Pikó Bettina (2006): Orvosi szociológia. Medicina Kiadó, Budapest.

20. Stiglitz, J. E. - Sen, A. - Fitoussi, J. P. (2009): A Bizottság jelentése a gazda sági teljesítmény és a társadalmi fejlődés méréséröl. Statisztikai Szemle, 3: 305-320.

21. Tahin Tamás - Jeges Sára - Lampek Kinga (2000): Iskolai végzettség és egészségi állapot. Demográfia, 1: 70-93.

22. Tokaji Károlyné - Faragó Miklós - Boros Julianna (2011): Objektíven szubjektív. Statisztikai Szemle, 7-8: 786-790.

23. Ware, J. E. (1986): The assessment of health status. In.: Aiken, L. H. - Mechanic, D. (eds.): Application of social science of clinical medicine and helath policy. Rutgers University Press, New Jersey. 204-208. 
